\title{
The Development of the Service Sector in Albania and Its Future
}

\author{
Oltiana Muharremi \\ Lecturer in Accounting and Finance, PhD student, \\ University of Vlora "Ismail Qemali" \\ olta.muharremi@gmail.com \\ Filloreta Madani \\ PhD in Finance, Lecturer in Accounting and Finance \\ University of Vlora "Ismail Qemali" \\ fcenolligmail.com \\ Erald Pelari \\ Lecturer in Finance \\ University of Vlora "Ismail Qemali" \\ epelari@gmail.com
}

\section{Doi:10.5901/mjss.2013.v4n10p556}

\section{Abstract}

Today citizens of the modern world are living in an economy that is increasingly based on services. The service sector is not anymore a minor part of the overall economy, but a major sector adding lots of value to the economy. The service industry represents the fastest growing economic sector. The objective of the paper is to analyze the service sector in Albania for the past few years and compare it with other countries within the European Union and countries in the Balkan area. Most of the work force in Albania is employed in the service sector, marketing numerous types of services to customers such as: food, personal care, entertainment, banking, insurance, transport, consultancy, tourism, office services, professional services, etc. Over the last 20 years, Albania has transformed from an agricultural economy to a service-oriented economy. The service sector in Albania is new and dynamic. Two main services where foreign direct investment is oriented are telecommunications and financial intermediation, $23 \%$ and $33 \%$ respectively. Telecommunications is the most dynamic service sector in the Albanian economy. The main aim of this research paper is to portray an analytical view of the Albanian service sector, their quality and the future development. The paper will provide information on services which are not well developed and have huge growth potential. The methodology employed in the paper is secondary research of accessible literature, statistic reports for OCED countries, EU countries from Euro stat, World Bank, Albanian Statistics Institute (INSTAT), as well as the Albanian Ministry of Finance and other recognized institutions.

Keywords: service sector, telecommunication, development of services, employment

\section{Definition of Service Sector}

The service sector consists of the "soft" parts of the economy, i.e. activities where people offer their knowledge and time to improve productivity, performance, potential, and sustainability. The basic characteristic of this sector is the production of services instead of end products. Services (also known as "intangible goods") include attention, advice, experience, and discussion. There are many definitions of what constitutes a service. Many definitions of services focus on the fact that the service itself does not produce tangible output, although it can be a tool for producing some tangible outputs. The production of information is generally also regarded as a service, but some economists now attribute it to a fourth sector, the quaternary sector.

The tertiary sector of the economy (also known as the service sector or the service industry) is one of three economic sectors, the others being the secondary sector (approximately the same as manufacturing) and the primary sector (agriculture, fishing, and extraction of raw minerals). The tertiary sector of industry involves the provision of services to other businesses as well as final consumers. Services may involve transportation, distribution, and sale of goods from producer to consumer, as may happen in wholesaling and retailing, or may involve the provision of a service, 
such as in pest control or entertainment. The goods may be transformed in the process of providing the service, as happens in the restaurant industry. However, the focus is on people interacting with people and serving the customer rather than transforming physical goods.

Examples of service sector employment include:

- Government

- Healthcare/hospitals

- Public health

- Waste disposal

- Education

- Banking

- Insurance

- Financial services

- Legal services

- Consulting

- News media

- Hospitality industry (e.g. restaurants, hotels, casinos)

- Tourism

- Retail sales

- Franchising

- Real estate

- Sales

\section{Introduction}

Today citizens of the modern world are living in economies that are increasingly based on services. Services are not a minor part of the economy, but are at the center of value creating within economies. The service industry represents the fastest growing economic sector in the world. According to Prof. Leonard Berry, from the marketing department at Texas A\&M University "A good is an object while a service is an act, a performance, an effort"(Berry L. 1994). This industry is spread out in various areas that include finance, insurance, transportation, communications, utilities, wholesale trade, retail, tourism, education, health, professional services, food, housing, leasing, etc.

\section{Economic Context of Albania}

Albania is a country that changed from a controlled economy during the communist regime to a democratic country with an open economy in 1990. Although the country is rich in natural resources, the economy is mainly bolstered by emigrant annual remittances, services, and the agricultural sector. In contrast to many other transition economies, macroeconomic stability in Albania in the early 1990s was followed almost immediately by a non-inflationary economic upsurge with the exception of 1996 and 1997, when Albania was faced with a major economic crisis triggered by the collapse of the pyramid investment schemes. Total liabilities of these schemes were estimated at almost 50\% of GDP in 1996. The economic impact of the crisis was severe; the Albanian lek lost half of its value. The loss of wealth in the pyramid schemes took the economy in a depression, remittances from abroad fell heavily (minus $47 \%$ ) which directly reduced investments in construction and other industries.

Table1: Key Macroeconomic indicators

\begin{tabular}{|c|c|c|c|c|c|c|}
\hline Indicators & Unit & 2008 & 2009 & 2010 & 2011 & 2012 \\
\hline Population & Million (ALL) & 2.9 & 2.88 & 2.86 & 2.83 & 2.83 \\
\hline The average inflation rate & $\%$ & 3.4 & 2.3 & 3.6 & 3.5 & 2 \\
\hline GDP Deflator & $\%$ & 4.7 & 2 & 2.6 & 3 & 2.2 \\
\hline Real GDP Growth & $\%$ & 7.5 & 3.3 & 3.8 & 3.1 & 1.5 \\
\hline GDP & Billion (ALL) & $1,089.3$ & $1,148.1$ & $1,222.5$ & $1,297.7$ & $1,346.2$ \\
\hline Unemployment Rate & $\%$ & 12.7 & 13.8 & 13.5 & 13.3 & 13.4 \\
\hline
\end{tabular}

Source: INSTAT, Albanian National Bank, Ministry of Finance, World Bank 
In the period after 1998, Albania experienced rapid economic growth (real GDP growth rates of more than 7\% per year), low inflation and a stable currency. Albania continued to pursue a sustainable economic policy until 2009. The economy was able to absorb the impact of the financial crises that rippled around all international markets in 2008. The risk of the financial crises reaching the Albanian economy was far closer due to the fact that a huge number of the world's biggest economies were experiencing full out economic crises. Over the last 2-3 years, the effects of the global crisis have made the Albanian economy more sensitive, decreasing the GDP growth rate yearly until it reached 1.5\% in 2012.

The slow decrease of GDP comes due to the close exposure the Albanian economy has with Greece and Italy. The main channels through which the Albanian economy is affected by developments in these countries are: demand for exports in report to remittances and foreign direct investment. In 2012 the country's economy was characterized by a slow but positive growth, stimulus fiscal policy, a relatively stable exchange rate, reduction of risk premiums, and low inflationary pressures from the demand side.

\section{Current Situations in the Albanian Service Sector}

Albania is a middle income country by Western European standards, with GDP per capita greater than several countries in the region. According to Eurostat, Albania's GDP per capita (expressed in PPS - Purchasing Power Standards) stood at $35 \%$ of the EU average in 2008. Unemployment rate of $13.3 \%$ is considerably lower than many countries in the Balkans. In 2012 Albania reached an unemployment level of 15\%, versus 13.30\% in 2011. Albania's economy is predominantly service-based. Agriculture accounts for $18.65 \%$ of GDP and employs $44.10 \%$ of the population. Manufacturing and other industries account for $15.82 \%$ of GDP and employ $19.90 \%$ of the population. Services accounts for $65.53 \%$ of the GDP and employs $36.00 \%$ of the population.

As is seen from the graph below in the years before 1990, the service sector made about $22.09 \%$ of GDP. The country's economy was mostly based on heavy industry and agriculture. The transition years from $1990-1995$ were difficult years for Albania and its economy. During these years heavy industry production was brought to a halt, and the entire economy was kept alive through remittances. The service sector was still in its infancy and contributed very little to the overall GDP, which increased with the consolidation of the rule of law and expansion of the private sector. Since 1995 the service sector became more consolidated and grew every year, until 2011which made about $65.53 \%$ of GDP, the highest ever in the economy. A major reason why the service industry experienced such growth is due to the increase in efficiency of the postal service, telecommunications, banking sector, insurance companies, and transportation.

Fig. 1. Value added in the service sector as percent of GDP in Albania

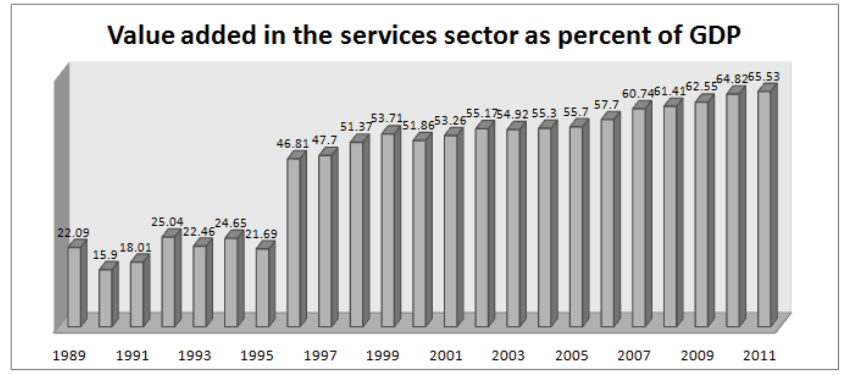

Sources: TheGlobalEconomy.Com, World Bank.

Figure 2 shows the percentage of people employed throughout the Albanian economic sector. The service sector is still growing while other sectors are falling down in terms of employment. The current employment situation as is shown in figure 2 indicates a strong presence in agriculture with $44 \%$ of the workforce, followed by the services sector with $36 \%$. Heavy industry is less developed and employs only $19.9 \%$ of all employees in Albania. 
Fig. 2. Employment by sector of the economy in Albania

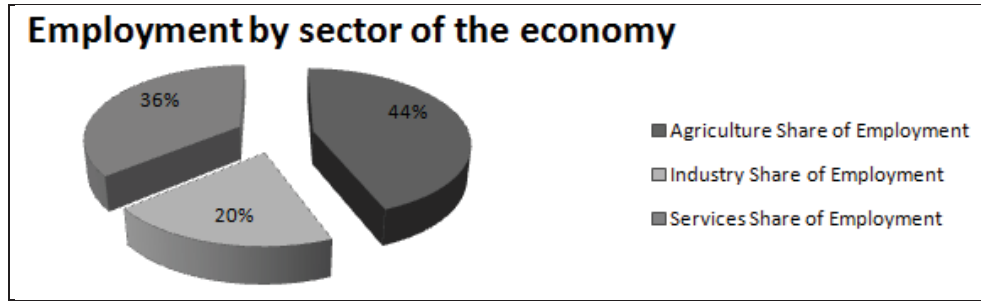

Sources: TheGlobalEconomy.Com, World Bank.

\subsection{Postal Services}

The Albanian Post has supremacy on the overall postal service market. It controls all prices and terms due to its huge market share, delivers packets with considerations of government regulations. The Albanian Post is a monopoly guaranteed by the government. There are also other companies who offer post services such as: FedEx, TNT, DHL, UPS and others, but these companies usually deliver abroad and are very expensive.

\subsection{Telecommunication}

Telecommunications represents one of the most dynamic sectors in Albania developed mainly through privatization and subsequent investment by foreign investors and to some extent from domestic investors as well. Albanian Mobile Communication (AMC) was the first operator to enter the mobile communication market in 1996. AMC at its beginning stages was a state owned company. Vodafone Albania was the second company that would be granted a license for mobile communication in 2001. Eagle Mobile was the third operator to enter the market in 2008, employing over 250 employees, while another 150 employees were hired by sub-contracting companies. In 2009 the Albanian government granted a fourth license for wireless communication to a domestically owned company "PLUS". The fixed-broadband operator Alb telecom privatized $76 \%$ of its government owned shares for a value of $€ 120$ million Euros to Calik Energy Telekomunikasyon (Turkey), together with its partner Turk Telekom. During 2005-2009 the number of fixed-broadband connections rose by nearly $30 \%$, while mobile new numbers contracted tripled. According to OECD (April 2010) the fixed line telephone contracts remains the lowest in Eastern Europe, while mobile telephony has grown rapidly.

Some key Albanian telecommunications industry data for 2012 show that there are at least 200,000 subscribers of fixed-broadband service in Albania, 80,000 more subscribers then in 2010. Meanwhile the current number for fixedtelephony subscribers stands at 340,000 up from 331,000 in 2010 . Another important indicator is wireless communication subscribers, which stand at 5.1 million in 2012. This is an increase from the 4.5 million subscribers in 2010. The entrance of the $3 G$ services has increased the number of subscribers who use network cards and modem devices. However experts recommend further regulatory measures in the underdeveloped mobile sector is needed.

\subsection{Banking Sector}

After the year 1990 all countries in the region went through a banking system restructuring process by privatizing state banks to foreign banking institutions. Most of these investors are from Austria, France, Greece and Italy. Foreign banks have had a positive impact on the financial system by strengthening risk management, increasing levels of fair competition, and providing more sophisticated financial products to their clients. The banking sector in Albania is in good condition, not only thanks to its privatization, but also due to the right monetary policy that provided support at the right time, through two rate cuts in interest rates and the injection of money supply through foreign exchange in 2009. Even with the right monetary policy put in place during the financial crises, foreign investors are still concerned for the financial system not only in Albania but in all Eastern European countries.

Bank lending slowed in all countries of Eastern Europe, while in Albania loans granted to the private sector continued to grow, only at a slower pace. Bad loans in Albania make about $12 \%$ of all loans, classifying it as the second 
country in the region with bad loans. Italian and Austrian banks have resisted the financial crisis, while banks of Greek subsidiaries are facing difficult times due to the economic crises.

\subsection{Insurance Companies}

In 2008 the number of insurance companies, foreign or domestic, that operated in Albania were 10; 7 of them offer nonlife insurance companies, two offer only life insurance and one offers both services. Insurance companies that offer nonlife insurance, according to their market share in Albania are: Sigal, Sigma, Insig Insurance Institute, Atlantic Interalbanian Albsig, Intersig and Eurosig. Sigal leads the market with approximately $27.2 \%$ of non-life premiums sold. On the other hand, insurance companies operating in the Albanian market have also increased their presence in nearby countries. Insig, Sigal, UNIQA Group and Sigma are present in Kosovo and Macedonia, while Albsig has established a branch only in Macedonia.

\subsection{Transportation}

Modernization of Albania's transport infrastructure is seen as central to sustainable trade and private-sector development, and at a more general level, economic growth and investment. Albania has scheduled General Agreement on Trade in Services (GATS) commitments on maritime, air, and road transport, as well as services auxiliary to all methods of transportation. The Stabilization and Association Agreement with the EU also has a transportation component to it as well that the Albanian government will have to abide too.

\subsection{Higher education}

Higher education is offered by 13 public universities and 46 private universities and faculties operating in Albania. In the academic year 2010/2011, a total of 86345 full-time students (excluding Ph.D. students) and 19084 part-time and distance learning students were enrolled in public higher education institutions and 26784 students in private institutions, with a full-time teaching staff of 4053 persons and part-time teaching staff of 572 .

\section{Foreign Direct Ivestment (FDI) in the Service Sector}

The service sector is the branch of the Albanian economy that attracts more foreign investors. According to data from the Institute of Statistics (INSTAT), in Albania over 2,269 business ventures are owned by foreign nationals. Over 1,500 of these business ventures or $67 \%$ of them operate in the service sector. Foreigners own about 700 trading companies and 120 companies in the transport and telecommunications sector. Foreign investment initiative is less engaged in the production sector of the economy, where there are currently 744 foreign owned companies. Of these companies $65 \%$ of them have invested in heavy industry, $33 \%$ in construction, and slightly more than $1 \%$ in agricultural and seafood products. The same trend applies predominantly in the service sector for joint ventures between Albanians and foreign investors. In Albania there are about 1,300 such ventures, of which 63\% operate in the service sector.

For the past 20 years, Albania has transformed from an agricultural economy to a service-oriented economy. The service sector is quite young and dynamic. Foreign Direct Investment in the service sector accounts for three quarters of the total FDIs in Albania's economy. In 2009, Albania received 717 million Euros from foreign investments, while in 2010 FDI inflows amounted to 793 million Euros. In 2010, Albania was ranked second in terms of the amount of FDI flows within countries of Eastern Europe, after Serbia. In 2011. Albania received 742 million Euros as foreign direct investments, 51 million Euros less then a year ago. As Albania is in the early stages of securing FDIs, most of them (approximately 80 percent in 2010 and even more in 2011) were in the form of equity in new businesses as well as additional equity invested in existing enterprises with foreign investors.

In 2011 FDI inflows rose only in energy and natural gas sector, for its distribution and other services, but declined in all other activities compared with a year ago. Most of the FDI went into the service sector, mainly in financial intermediation. The high level of FDI in the financial services in 2008 was as result of the acquisition of shares of Popular Bank (Banka Popullore) and Union Bank from foreign investors. Since that time, FDI in the intermediate financial sector has declined, mainly as a consequence of the European financial crisis. The types of FDIs in the Albanian market up to know have been primarily focused on production services geared towards the local market. 
Telecommunications and intermediate financial institutions are the two main services which FDI is oriented at, with $23 \%$ and $33 \%$ respectively of total investments. Telecommunications is the most dynamic service sector of the Albanian economy. FDIs in this sector were introduced through privatizations and current investments. In the intermediate financial sector, where FDls are perhaps influenced by the size of the investment but also from the legal grounds, foreign investors appear more widely. It is characteristic of countries in transition in their early stages of a free market economy development the financial sector development is preceded by the improvement of the banking sector. Various scholarly studies show that the presence of banks in developing countries is a prerequisite for generating FDI in other sectors of the economy from foreign financially sound companies.

Among the most important recipients of FDI in 2007 were wholesalers and retailers, but their share in total FDI declined in the coming years. Supermarket chains that dominate the retail sector in new member states of the EU are in the early stages of expansion in Albania. Besides METRO Group (Germany), which has invested in a wholesale store in Albania, the other foreign company offering its services in wholesale and retail trade is the Italian supermarket giant Conad. Activities in real estate by foreign affiliates also remain marginal, accounting for only $2 \%$ of FDls. Somewhat more important has been the development of "other business activities" including consulting, IT, and call centers, which accounted for approximately 4\% of FDIs in 2010. Since 2007 business operations and information technology services have increased and are expected to have positive growth compared to other countries in the region. Albania's close proximity to Italy and the good language skills of Italian by Albanians have made possible the creation of 'call centers'. Among the pioneers to invest in call centers in Albania are Italian Answer Group and Tele performance.

Fig. 3. Foreign Direct Investment in Albania's Service Sector (Data in Mil Albanian Lek)

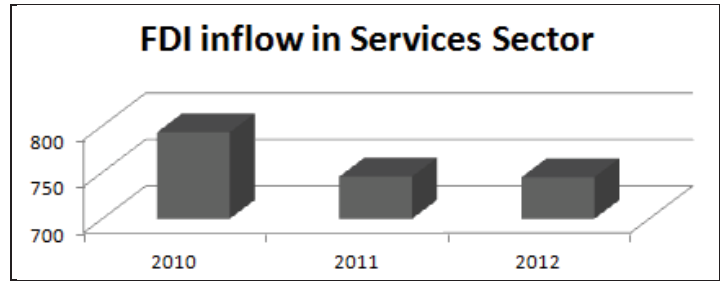

Sources: INSTAT

As seen from Table 4 investments in the service sector in the past few years have undergone major fluctuations, sometimes declining into negative numbers. It is evident and understandable that the financial crisis have affected this sector as well, where many foreign entrepreneurs have considered such investments too risky. In 2006 this sector of the economy experienced an investment boom with a 26.4\% increase, whereas in 2012 a huge decline in direct investment is noticed even going down to as much as $-8.4 \%$. The various factors that have affected either the increase or decrease in FDI investments in the service sector rise not only from negative economic or financial trends in the country, but also the nation where the investment is realized.

Table 4: The percentage increase of FDIs in the Service Sector

$\begin{array}{ccccc}\text { Year } & \text { Transport } & \begin{array}{c}\text { Post \& } \\ \text { Telecommunication }\end{array} & \begin{array}{c}\text { Other } \\ \text { Services }\end{array} & \begin{array}{c}\text { Matured Intermediate } \\ \text { Financial Services }\end{array} \\ 2005 & 15.2 & 11.4 & 3.6 & 4.3 \\ 2006 & -3.4 & 28.1 & 7.3 & 26.4 \\ 2007 & -5.1 & 12.8 & 13.7 & 7 \\ 2008 & 5.1 & 28.5 & -3 & 12.1 \\ 2009 & -3.2 & -9.9 & 3.4 & 6.9 \\ 2010 & 22.2 & 0.5 & 4.9 & 2.5 \\ 2011 & 4 & 7.9 & 0.9 & 5.6 \\ 2012 & -8.4 & 24 & 7.8 & 8.4\end{array}$

Sources: INSTAT 2013 


\section{Difference with Other European Countries}

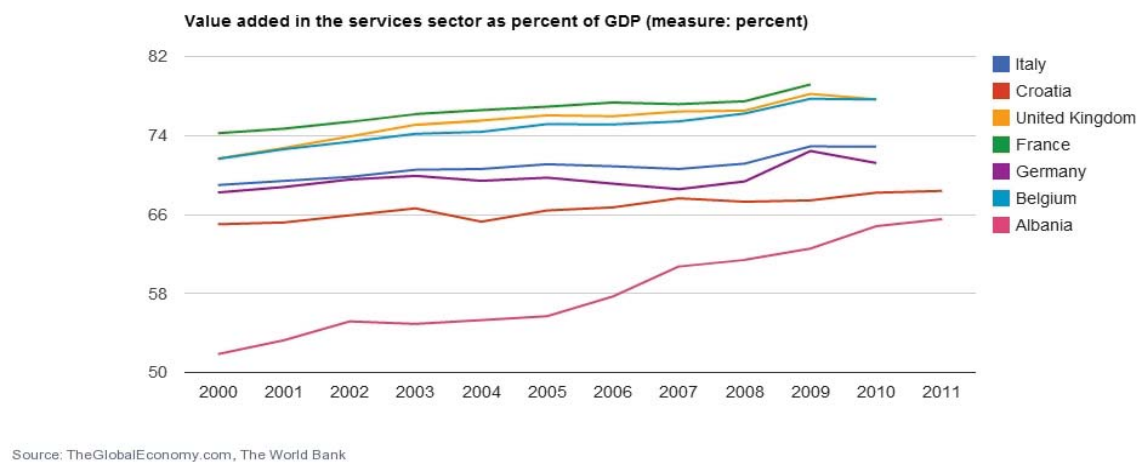

The service sector in Albania is constantly increasing as shown by the graph above from the World Bank. In 2011 it amounted to $65.53 \%$ of the total GDP, far lower then countries in the EU which amounts to more then $70 \%$ of their GDP. In reality Albania is still a nation trying to get the candidate status to enter the EU and does not receive the funds and subsidies that other EU countries receive from the union. European countries continue to pride themselves on their rich industrial heritage and strong global position in high-end manufacturing. Yet the underlying reality is that manufacturing is playing a steadily diminishing role in both employment and output. In contrast, the service sector accounts for around two-thirds of total EU output, and for four-fifths of growth in recent years. In terms of employment growth, the dominance of services is even more striking. With few exceptions, manufacturing employment in the EU has contracted, thus total employment expansion comes from either services or construction.

One important observation is that the services sector accounts for as much as three- quarters of cross-country differences in economic growth across individual EU countries. Relatively fast-growing countries have also typically had above-average productivity growth. Even though productivity growth is generally lower in the service sector than in manufacturing, it nevertheless accounts for a large share of aggregate growth in output per employee because of its large size. It is not unlikely that the economic crisis of recent years has sped up this process of deindustrialization in Europe, as a number of traditional sectors are confronted with overcapacity. Yet, the EU economy must find ways to expand faster in coming years in order to both replace the jobs lost during the crisis and to provide incomes with which excessive debt burdens are to be reduced (Uppenberg, Kristian. July 2010).

\section{Conclusions}

The service sector occupies an important place in modern economies. As much as about $55 \%$ of jobs are being offered by the service sector by marketing numerous types of services to customers, such as food, personal care, entertainment, banking, insurance, transport, consultancy, tourism, office services, professional services, etc. Service sector has a vital role to play in the economic, political and administrative changes that are taking place in Albania.

With the increasing awareness consumers look forward to a better service sector, these expectations may be more. With a democratic political setup and too many expectations from the government's side will lead to deterioration in the quality of service to be provided. With the plan of expansion in new areas asking for introduction of new services and other areas demanding improvement in quality of service, the government is constantly under pressure to provide services quantitatively and qualitatively. Therefore, the public agencies should venture into professional management to bring about result-oriented businesses.

The service sector management as a profession would contain the following:

1. Service deliverers - This involves the pure service rendered by the professional staff like doctors in hospitals, teachers in academics.

2. Service managers - The personnel who provide the supporting managerial services like administration - e.g. a registrar in a University. 
3. Service analysts - People who are entrusted with the task of concurrent review and evaluation of services in the organization - e.g. personal manager in a Human Resources

4. Supporting staff - Personnel employed in manual jobs in the service organizations such as nurses in hospitals.

From what was written above in this research paper investments in financial services and telecommunications are due to state privatizations of government owned entities and the opening of the Albanian economy. The new foreign companies that acquired other companies through privatization invested substantial capital that positively affected the entire Albanian economy. Attracting more FDls in these services as well as in other sectors of the economy-the government should keep in mind that the services sector does not affect the growth of exports and consequently the need to improve the trade balance acquires intensification of policy changes to facilitate the conditions of doing business in Albania. Another important factor for attracting foreign investors is the low salaries received by all levels of the workforce. The average monthly gross salary in Albania is around $€ 150$ - competitive on a global level. Wages in service firms are significantly higher than in the economy as a whole, but are still highly competitive at around one-third to onefifth the level of those in EU countries.

Albania offers a unique, low cost operations centre for service activities serving the Italian, Greek and Englishspeaking markets. Albania is unique in that approximately $70 \%$ of the population speaks Italian and $30 \%$ speaks Greek, making Albania the only offshore location that can provide front and back offices services for these markets, resulting in cost savings of up to $75 \%$.

Among the important factors for further growth of business services are a well trained workforce as well as better services of fixed broadband communications. The hotel and restaurant industry represents $1 \%$ of the total investment form FDIs, while Albania has good potential in attracting tourists that appreciate nature untouched by the human hand. Investments are scarce in the area of legal consulting services, the presence of which would be necessary for all domestic and foreign investors. Foreign Direct Investments can expand rapidly with the implementation of the recommendations mentioned above.

\section{References}

Albanian Financial Supervisory Authority (2012a), Annual Report 2008. Viewed at: http://amf.gov.al/pdf/publikime2/raport/amf/ RaportVjetor2012.pdf

Albanian Financial Supervisory Authority (2009b), Statistics Insurance Market, January - July 2009. Viewed at: http://amf.gov.al/pdf/ publikime/Korrik\%202009\%20Sigurime\%20Raport.pdf.

Aleksi, Ina (2003), Privatization and Various Structural Reforms in Albania, Kalo \& Associates. Viewed at: http://www.seelegal.org/upload/documents/Albania/Albania_Article_1.doc.

Annual report of FDI in Albania 2011. Viewed at: http://www.mete.gov.al/doc/web_fdi_report_albanian.pdf

Bank of Albania online information. Viewed at: http://www.bankofalbania.org/web/Time_series_22_2.php?evn=agregate_detaje\&evb $=$ agregate\&cregtab_id $=535 \&$ periudha_id $=5$.

Berry, Leonard L., Parasuraman, A. and Zeithaml,Valarie A.: Improving service quality in America: Lessons learned, Academy of Management Executive, 1994 Vol. 8 No. 2

Dajkovic, Irena (2004). Competing to Reform: An Analysis of the New Competition Law in Albania, European Bank for Reconstruction and Development's. Viewed at: http://www.ebrd.com/country/sector/law/articles/dajkovic.pdf.

EBRD (2006); Strategy for Albania: As approved by the Board of Directors on 4 April 2006. Viewed at: http://www.ebrd.com/about/ strategy/country/albania/albania.pdf.

FMN (2010a). World Economic Outlook: Recovery, Risk and Rebalancing. Washington, D.C.: FMN.

IMF (2009), Albania: Sixth Review Under the Three-Year Arrangement Under the Poverty Reduction and Growth Facility, Review Under the Extended Arrangement, and Financing Assurances Review-Staff Report; Staff Statement; Press Release on the Executive Board Discussion; and Statement by the Executive Director for Albania, IMF Country Report No. 09/73, Washington, D.C., February 2009. Viewed at: http://www.imf.org/external/pubs/tt/scr/2009/cr0973.pdf.

UNDP, The Services Sector in Albania (Sector review and inward investment opportunities) September 2005.

UNDP (2009) Human Development Report 2009. Viewed at: http://hdr.undp.org/en/media/HDR_2009_EN_Complete.pdf.

Uppenberg, K. and Strauss, H. Innovation and productivity growth in the EU services sector. july 2010 . Viewed at: http://www.eib.org/ attachments/efs/efs_innovation_and_productivity_en.pdf

World Bank online information. Viewed at: http://go.worldbank.org/9JRAQLVG50;

World Bank (2010). Investing across borders 2010, Indicators of foreign direct investment regulations in 87 countries. Washington, D.C., World Bank 